\title{
Quantitative sputum culture as a means of excluding false positive reports in the routine microbiology laboratory
}

\author{
M. J. B. WILSON AND D. E. MARTIN \\ From the Department of Microbiology, Royal Perth Hospital, Perth, Western Australia
}

SYNOPSIS A relatively simple technique for sputum homogenization and dilution is described. Results show that this technique is reliable for isolation and quantitative culture of organisms from cases of chest infection. The technique has resulted in significant reduction in false positive reports, particularly when a system of interpretative reporting is utilized based on $10^{7}$ organisms per millilitre of sputum being accepted as evidence of significant infection.

The bacteriology of human excretions, particularly sputum and urine, has given rise to considerable difficulties in interpretation. Kass (1957) contributed much to the better understanding of the significance of non-catheter urine culture when he introduced the concept of colony counts, in an effort to distinguish between infected urine and urine from normal persons contaminated by urethral flora. Lower respiratory tract infections may likewise show a heavy growth of commensal organisms, because of the necessity to traverse a heavily contaminated oropharynx. In respect to sputum sampling there are additional difficulties in view of the lack of homogeneity within the specimen. Results of sputum culture have been improved following the development of digestion techniques, but in using these combined with direct culture there is still difficulty in deciding whether the bacteria grown are significant or not, and no reliable measurement of bacterial numbers is possible. Dixon and Miller (1965) investigated the value of diluting sputum before culture. They concluded that a routine dilution of $10^{-4}$ excluded the great majority of contaminating organisms and allowed a more meaningful report to be made. Monroe, Muchmore, Felton, and Pirtle (1969) quantitated microorganisms in the sputum of a group of patients with pneumonia, and they found that probable pathogens occurred in numbers of $10^{7}$ organisms per ml or greater. This work was confirmed and extended by Pirtle, Monroe, Smalley, Mohr, and Rhoades (1969).

Received for publication 19 January 1972.
A critical analysis of sputum culture results from our laboratory showed that there was frequently a good growth of a potential pathogen when clinical evidence for infection was equivocal and there was a tendency for the laboratory to make an excessive number of false positive reports using standard culture methods. These false positive reports are misleading and make it difficult to manage cases effectively, and they may lead to unwarranted and undesirable antibiotic usage.

The combined technique of sputum homogenization and quantitative culture has definite advantages, but to be of use in the busy diagnostic laboratory it needs to be relatively simple and economical of time and materials. Mucoid sputum is a difficult material to process and with this in mind we have adopted a dilution technique which is practical, simple, and quick. The aim of the present study has been to utilize this technique for sputum dilution and quantitative culture in an endeavour to improve the correlation between the laboratory report and the patient's actual clinical condition. The presence of potential pathogens in sputum at a number greater than $10^{7}$ organisms per $\mathrm{ml}$ was considered to be compatible with active infection, and this level of significance is the same as that adopted by Monroe et al (1969).

A series of 200 consecutive specimens of sputum was cultured using the dilution technique. Results were compared with a standard straight plating method in which sputum was homogenized but not diluted. Results of both cultures were correlated with an objective clinical and radiological assessment of the lower respiratory tract of each patient. 


\section{Method}

Sputum was collected in the wards without any special instructions from the laboratory. Specimens subject to delay were refrigerated.

\section{DILUTED CULTURE TECHNIQUE}

1 Weigh sputum and container on a Metler K17 balance.

2 Add $2 \mathrm{ml}$ of $2 \% \mathrm{~N}$ acetyl $\mathrm{L}$ cysteine to the sputum and shake at room temperature for five minutes using a Dynamax flask shaker.

3 Pour liquefied sputum into $100 \mathrm{ml} 0 \cdot 1 \%$ peptone saline and shake before further dilution.

4 Reweigh container to determine the weight of sputum by difference. Each gram of sputum was considered to have a volume equivalent to $1.0 \mathrm{ml}$. 5 Make a further dilution of the first peptone sputum mixture into a second $100 \mathrm{ml}$ of peptone saline to give final dilution $10^{-4}$. The actual volume used, depending on the weight of the original sputum, eg, $2 \mathrm{ml}$ of original sputum pipette $0.5 \mathrm{ml}$ peptone sputum mixture; $0.5 \mathrm{ml}$ pipette $2 \mathrm{ml}$.

6 A standard dropper delivering 40 drops per $\mathrm{ml}$ was used to dispense 1 drop of the $10^{-4}$ sputum dilution onto the surface of a culture plate and spread.

Culture media used were Ward and Rudd plate incubated anerobically, MacConkey plate, blood plate, and a chocolate bacitracin plate (for haemophilus sp) all incubated aerobically at $37^{\circ} \mathrm{C}$.

\section{UNDILUTED CULTURE TECHNIQUE}

The surfaces of culture plates were inoculated with homogenized sputum using a wire loop.

\section{ASSESSMENT OF GROWTH ON PLATES}

Growth of potential pathogens using diluted and undiluted sputum was recorded as no growth, less than 25 colonies, $25-100$ colonies, $100-400$ colonies, confluent growth.

Bacteria were identified according to the text of Cowan and Steel.

CLINICAL ASSESSMENT OF PATIENTS

Assessment was retrospective by means of case records. The following criteria were evaluated: clinical examination, the chest $x$-ray report, leucocyte count, presence or absence of fever, response to any antibiotic administered. Using these criteria, each case was classed as probable lower respiratory tract infection or probable absence of lower respiratory tract infection.

The majority of cases were readily classified using these criteria; however, a small number of the cases were difficult to classify and these were referred to an independent assessor for his opinion. If a case could not be classified by either the original observer or the independent assessor it was excluded from the study (two cases).

\section{Results and Discussion}

For the purpose of this study we have defined a pathogen as any organism other than Neisseria sp, Streptococcus viridans, Staph. epidermidis, or diphtheroid bacilli.

The number of specimens received was 200 which were contributed by 145 patients. Each patient was assessed according to the criteria already indicated, on each day that he contributed a specimen of sputum which was included in the series. For this reason a patient may have been initially assessed as having a chest infection and later on in the course of his illness following treatment he may then have been assessed as not infected.

Bacteriological investigations depend entirely upon the reliability of the specimen received, and it is obvious that a specimen consisting mainly of saliva cannot be expected to reflect the bacteriology of the lower respiratory tract. It follows that any patient in whom a respiratory tract infection is suspected will benefit from the assistance of a physiotherapist in obtaining a good sample of sputum. If bronchial occlusion exists and sputum fails to drain from the affected portion of the respiratory tract there will inevitably be a failure to isolate a meaningful pathogen.

From a technical point of view, colony counts on diluted sputum have many advantages despite the extra bench procedure required. Any time lost in setting up the sputum is more than compensated for by the time saved when plates, which are not obscured by large numbers of superfluous oral microorganisms, are examined. More importantly, we feel that the dilution technique gives a much better correlation between the clinical condition of the patient and the bacteriological report. From the results presented in Table $I$ it can be seen that undiluted and diluted sputum cultures were comparable in respect of the isolation of potential

\begin{tabular}{lllll}
\hline Technique & $\begin{array}{l}\text { Isolations } \\
\text { Theoretically } \\
\text { Possible }\end{array}$ & $\begin{array}{l}\text { Specimens } \\
\text { Growing } \\
\text { Pathogens }\end{array}$ & $\begin{array}{l}\text { Percentage } \\
\text { 'Successful' } \\
\text { Cultures }\end{array}$ & $\begin{array}{l}\text { No. of } \\
\text { Patients } \\
\text { Yielding a } \\
\text { Pathogen }\end{array}$ \\
\hline $\begin{array}{l}\text { Undiluted } \\
\text { Diluted }\end{array}$ & 57 & 40 & 70 & 29 \\
\hline
\end{tabular}

Table I Results on 57 specimens from 39 patients with probable lower respiratory tract infections ${ }^{1}$

${ }^{1}$ Based on isolation of a potential pathogen with no consideration given to numbers of bacteria present. 
pathogens from cases with probable clinical infection. Failure to isolate a pathogen in a number of the patients with probable lower respiratory tract infection could in some cases be related to factors such as prior antibiotic treatment, inadequate specimen collection, and in one patient a probable diagnosis of psittacosis. Using the criteria of interpretative reporting which is discussed in the following paragraph, five of the 37 specimens coming from patients with probable clinical infection gave a growth of less than 25 colonies per plate. In the corresponding undiluted examination of the same sputum four of these specimens also gave a scanty or ambiguous growth of the equivalent organism, the other yielding a moderate growth of Pseudomonas species.

The dilution technique had a considerable advantage in that fewer positive reports were made on sputum from uninfected cases. Table II records the isolation of potential pathogens from sputum in cases showing no evidence of lower respiratory tract infection. It can be seen that false positive isolations

\begin{tabular}{lllll}
\hline Technique & $\begin{array}{l}\text { False } \\
\text { Positives } \\
\text { Theoretically } \\
\text { Possible }\end{array}$ & $\begin{array}{l}\text { Specimens } \\
\text { Growing } \\
\text { Potential } \\
\text { Pathogens }\end{array}$ & $\begin{array}{l}\text { Percentage } \\
\text { False } \\
\text { Positive } \\
\text { Cultures }\end{array}$ & $\begin{array}{l}\text { No. of } \\
\text { Patients } \\
\text { Yielding } \\
\text { Pathogens }\end{array}$ \\
\hline Undiluted $^{1}$ & 143 & 51 & 36 & 41 \\
Diluted $^{1}$ & 143 & 30 & 21 & 28 \\
Diluted $^{2}$ & 143 & 19 & 13 & 13 \\
\hline
\end{tabular}

Table II Results in 143 specimens from 118 patients with no respiratory infection

${ }^{1}$ Based on isolation of a potential pathogen with no consideration given to numbers of bacteria present.

${ }^{2}$ Based on $10^{7}$ organisms per $\mathrm{ml}$ of sputum being evidence of significant infection.

occurred in $36 \%$ of specimens using an undiluted technique; however, using the diluted technique, this was reduced to $21 \%$ which represented a significant improvement. In the same group of patients even better correlation between the clinical state and the culture report was obtained when specimens yielding less than 25 colonies per plate, or less than $10^{7}$ organisms per $\mathrm{ml}$ of the original sputum specimen, were interpreted as being of doubtful significance. This finding has prompted us to institute a system of interpretative reporting in which three types of report are possible: (1) A significant growth of a pathogen (greater than 25 colonies on the plate or greater than $10^{7}$ organisms per $\mathrm{ml}$ of original sputum); (2) growth of a pathogen in such numbers that the significance is doubtful (less than 25 colonies per plate); (3) no pathogen isolated (no potential pathogen cultured).
Further reference to Table II shows that using this method of reporting the isolation of potential pathogens from patients without lower respiratory tract infection reduced the number of false positive reports from 36 to $13 \%$.

Using direct plating of undiluted sputum 41 of 118 patients without clinical chest infection would be potentially exposed to antibiotic therapy with risk of side effects, not to mention discomfort, and economic factors. In our experience, a not insignificant number of falsely positive sputum culture reports are acted upon, often with use of drugs such as colistin and gentamycin as the organism is often a Gram-negative bacillus.

Using the dilution technique a pathogen would be isolated in 28 patients. Using interpretative reporting in addition, doubt would have been cast on the significance of the pathogen isolated in a further 15 patients so that 13 of 118 patients would have received false positive interpretation, as compared with 41 using present standard methods. In our view this represents a very worthwhile improvement in accuracy. Patients with atypical pneumonia are more likely to have the aetiological agent identified if the picture is not obscured by a laboratory report stating isolation of a bacterial pathogen which is not present in significant numbers.

\begin{tabular}{llc}
\hline Bacteria & $\begin{array}{l}\text { From Infected } \\
\text { Patients }\end{array}$ & $\begin{array}{l}\text { From } \\
\text { Patients }^{1}\end{array}$ \\
\hline Streptococcus pneumoniae & 10 & 9 \\
Haemophilus influenzae & 4 & 6 \\
Haemophilus parainfluenzae & 2 & - \\
Staphylococcus aureus & 5 & 5 \\
Pseudomonas aeruginosa & 8 & 7 \\
Klebsiella sp. & 5 & 13 \\
Escherichia coli & 2 & 3 \\
Other Gram-negative organisms & 3 & 16 \\
Candida sp. & - & 8 \\
Streptococcus faecalis & - & 1 \\
\hline
\end{tabular}

Table III Bacteria isolated

${ }^{1}$ Some grew morc than one organism.

${ }^{2}$ Generally not considered a pathogen.

'Includes Proteus sp., Enterobacter sp, Achromobacter, Alkaligines, and Bacterium anitratum.

From the results presented it can be seen that the technique of sputum dilution before culture is as reliable in cases with probable chest infection as the more concentrated culture of homogenized sputum. However, in respect of the examination of sputum from uninfected cases it has the marked advantage of eliminating from serious consideration those organisms which, although potential pathogens, are present in sputum at a count of less than $10^{7} \mathrm{ml}$, ie, if a microorganism is present in relatively small 
numbers it is probably not significant. The study reported has shown a marked reduction in false positive reports in cases where sputum was cultured quantitatively and the criterion for infection considered to be more than 25 colonies of a given potential pathogen on the dilution plate.

We wish to thank Dr E. R. Pavillard, microbiologist, Royal Perth Hospital, for his encouragement, and helpful criticism of this paper.
References

Cowan, S. T., and Steel, K. J. (1965). Identification of Medical Bacteria. Cambridge University Press. London.

Dixon, J. M. S., and Miller, D. C. (1965). Value of dilute inocula in cultural examination of sputum. Lancet, 2, 1046-1048.

Kass, E. H. (1957). Bacteriuria and the diagnosis of infections of the urinary tract. Arch. intern. med., 100, 709-714.

Monroe, P. W., Muchmore, H. G., Felton, F. G., and Pirtle, K. J. (1969). Quantitation of microorganisms in sputum. Appl. Microbiol., 18, 214-220.

Pirtle, J. K., Monros, P. W., Smalley, T. K., Mohr, J. A., and Rhoades, E. R. (1969). Diagnostic and therapeutic advantages of serial quantitative cultures of fresh sputum in acute bacterial pneu. monia. Amer. Rev. resp. Dis., 100, 831-838.

\section{Reports and Bulletins prepared by the Association of Clinical Biochemists}

The following reports and bulletins are published by the Association of Clinical Biochemists. They may be obtained from The Administrative Office, Association of Clinical Biochemists, 7 Warwick Court, Holborn, London, WC1R 5DP. The prices include postage, but air mail will be charged extra. Overseas readers should remit by British Postal or Money Order. If this is not possible the equivalent of $50 \mathrm{p}$ is the minimum amount that can be accepted.

\section{SCIENTIFIC REPORTS}

3 Automatic Dispensing Pipettes. An assessment of 35 commercial instruments 1967 P. M. G. BROUGHTON, A. H. GOWENLOCK, G. M. WIDDOWSON, and K. A. AHLQUIST $85 \mathrm{p}(\$ 2)$

4 An Evaluation of five Commercial Flame Photometers suitable for the Simultaneous Determination of Sodium and Potassium March 1970 P. M. G. BROUGHTON and J. B. DAWSON $85 p(\$ 2)$

\section{SCIENTIFIC REVIEWS}

1 The Assessment of Thyroid Function March 1971 F. V. FLYNN and J. R. HOBBS $62 \frac{1}{2} \mathrm{p}(\$ 1.50)$

2 Renal Function Tests Suitable for Clinical Practice January 1972 F. L. MITCHELL, N. VEALL, and R. W. E. WATTS $62 \frac{1}{2} \mathrm{p}(\$ 1.50)$

\section{TECHNICAL BULLETINS}

9 Determination of Urea by AutoAnalyzer November

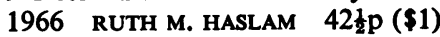

11 Determination of Serum Albumin by AutoAnalyzer using Bromocresol Green October 1967 B. E. NORTHAM and G. M. WIDDOWsoN $42 \frac{1}{2} p(\$ 1)$

13 An Assessment of the Technicon Type II Sampler Unit March 1968 B. C. GRAY and G. K. MCGOWAN 42tp (\$1)

14 Atomic Absorption Spectroscopy. An outline of its principles and a guide to the selection of instruments May 1968 J. B. DAWSON and P. M. G. BROUGHTON 42 l $\mathrm{p}(\$ 1)$
15 A Guide to Automatic Pipettes (2nd edition) June

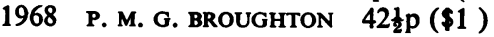

16 A Guide to Automation in Clinical Chemistry May 1969 P. M. G. BROUGHTON 621 p (\$1.50)

17 Flame Photometers (2nd edition) 1969 P. WILDING $62 \frac{1}{2} \mathrm{p}(\$ 1.50)$

18 Control Solutions for Clinical Biochemistry (4th edition) March 1970 P. M. G. BROUGHTON $62 \frac{1}{2}$ p (\$1.50)

19 Spectrophotometers. A comparative list of low-priced instruments readily available in Britain May 1970

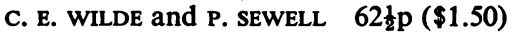

20 Quantities and Units in Clinical Biochemistry June

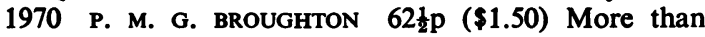
30 copies in units of 10 at 20p

21 Filter Fluorimeters: A comparative list of 18 instruments September 1970 H. BRAUNSBERG and s. $s$. BROWN $62 \frac{1}{2} \mathrm{p}(\$ 1.50)$

22 Bilirubin standards and the Determination of Bilirubin by Manual and Technicon AutoAnalyzer Methods January 1971 BARBARA BILLING, RUTH HASLAM, and N. WALD 621 $\mathrm{p}(\$ 1.50)$

23 Interchangeable Cells for Spectrophotometers and Fluorimeters September 1971 E. S. BROWN and A. H. GOWENLOCK 62tp (\$1.50)

24 Simple Tests to Detect Poisons March 1972 B. W. MEADE et al. $\quad 62 \frac{1}{2} \mathrm{p}(\$ 1.50)$

25 Blood Gas Analysers May 1972 K. DIXON 621 p (\$1.50) 